\title{
Two new species of Astyanax (Ostariophysi: Characiformes: Characidae) from eastern Brazil, with a synopsis of the Astyanax scabripinnis species complex
}

\author{
Vinicius A. Bertaco and Carlos A. S. de Lucena
}

Two new species of Astyanax are described from eastern Brazil: A. microschemos from the córrego Palmital, rio Itapemirim drainage, Espírito Santo, and A.pelecus from the rio Pardo drainage, Bahia. Astyanax microschemos differs from its congeners by its shallower body depth, $26.9-29.7 \%$ of standard length, the presence of one vertically elongate humeral spot that extend above and below the lateral line, smaller interorbital width, 26.9-30.4\% of head length, and the possession of 14-18 branched anal-fin rays. Astyanax pelecus differs from its congeners in the possession of only one humeral spot limited to the region dorsal to the lateral line, conspicuous, dark, midlateral body stripe extending from the upper margin of the opercle to the caudalfin base, a shallower body depth, 26.7-34.8\% of standard length, and the possession of 16-18 branched anal-fin rays, 38-39 scales in the lateral-line series, and four scales between the lateral line and the pelvic-fin origin. Astyanax microschemos has a massive head, short snout, usually smaller than the orbital diameter, shallow body depth, and vertically-elongate humeral spot that serve to include it in the $A$. scabripinnis species complex. A comparative synopsis of this complex is provided.

Duas novas espécies de Astyanax são descritas do leste do Brasil: A. microschemos, do córrego Palmital, drenagem do rio Itapemirim, Espírito Santo e A. pelecus, do rio Pardo, Bahia. Astyanax microschemos difere das demais espécies do gênero pela pequena altura do corpo de 26,9-29,7\% no comprimento padrão, uma única mancha umeral verticalmente alongada, estendendose acima e abaixo da linha lateral, estreita largura inter-orbital, 26,9-30,4\% no comprimento da cabeça e 14-18 raios ramificados na nadadeira anal. Astyanax pelecus difere das demais espécies do gênero pela presença de uma única mancha umeral situada dorsalmente à linha lateral, uma conspícua faixa escura lateral que vai desde o canto superior do opérculo até a base dos raios caudais, baixa altura do corpo (26,7-34,8\% no comprimento padrão), 16-18 raios ramificados na nadadeira anal, 38 a 39 escamas da linha lateral, e quatro escamas entre a linha lateral e a origem da nadadeira pélvica. Astyanax microschemos possui a cabeça larga, focinho curto, geralmente menor que o diâmetro orbital, e com perfil abrupto, corpo baixo e mancha umeral verticalmente alongada, caracteres que permitem sua alocação no complexo de espécies $A$. scabripinnis. É fornecida uma sinopse comparativa das espécies que supostamente fazem parte deste complexo.

Key words: Neotropical, taxonomy, Astyanax microschemos, Astyanax pelecus.

\section{Introduction}

Astyanax Baird \& Girard, 1854 is a speciose genus of Neotropical characid fishes, comprising about 86 valid described species (Lima et al., 2003) and occurring in diverse habitats within freshwater drainages from southern United States to central Argentina. Numerous new Astyanax species have been described in recent years, including ten new species in 2003 and 2004 (Eschmeyer, 2005). The nominal species currently assigned to Astyanax probably do not represent a monophyletic entity (Weitzman \& Malabarba, 1998); a situation that has been long recognized for the genus (Rosen, 1972). The cur- rent definition of Astyanax is based on the combination of characters proposed by Eigenmann (1917), which are, however widespread among genera in the Characidae, i.e. two rows of premaxillary teeth, five teeth in the inner premaxillary series, lateral line complete, adipose fin present, and caudal fin naked.

The examination of Astyanax samples reveals two undescribed species from the rio Pardo and rio Itapemirim, coastal drainages of Bahia and Espírito Santo states, respectively, which are herein described. This region possesses an endemic ichthyofauna that is presently suffering large anthropogenic impacts. This situation makes it timely to de-

Laboratório de Ictiologia, Museu de Ciências e Tecnologia, Pontifícia Universidade Católica do Rio Grande do Sul, Av. Ipiranga 6681, Caixa Postal 1491, 90619-900 Porto Alegre, RS, Brazil. e-mails: ubertaco@pucrs.br(VAB), lucena@pucrs.br(CASL) 


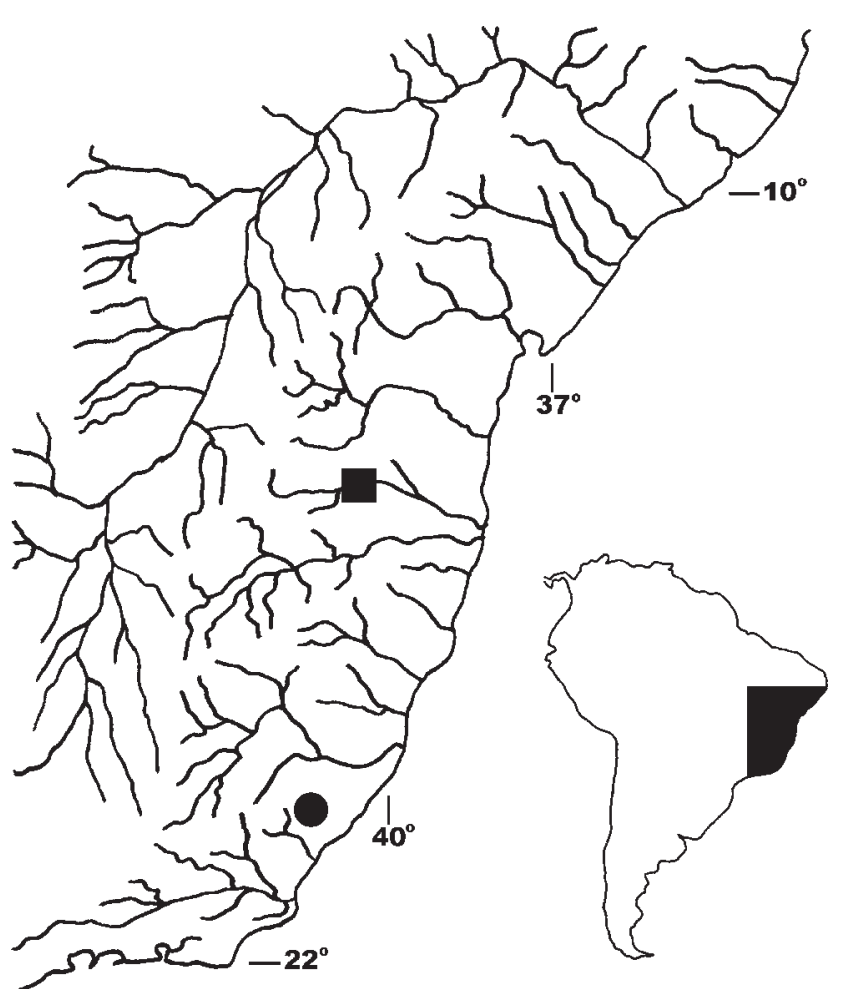

Fig. 1. Coastal drainages of states of Espírito Santo and Bahia, eastern Brazil, showing the distribution of Astyanax microschemos (dot) and Astyanax pelecus (square).

scribe these new species. One of the new species belongs to the Astyanax scabripinnis complex, a non-monophyletic group previously proposed by Moreira-Filho \& Bertollo (1991) and further discussed by Bertaco \& Malabarba (2001). In order to focus the discussion of the species diversity to a limited number of similar species, we utilize the following combination of characters that include those of Eigenmann (1921:273) as diagnosing A. scabripinnis, to delimit the $A$. scabripinnis species complex: body deepest and heaviest in area proximate to middle of pectoral fins, head heavy, snout short and abrupt by tapering, body depth smaller than $41 \%$ of SL (mean 30-33\% of SL), reduced number of branched anal-fin rays (13-21, usually 17-18, rarely 22 or 23), presence of one or two humeral spots, and a dark, midlateral, body stripe extending to the tip of the middle caudal-fin rays.

\section{Material and Methods}

Counts were taken as described by Fink \& Weitzman (1974), with the exception of the number of scale rows below the lateral line which were counted from the scale row ventral to lateral line to the scale row nearest to the origin of first pelvicfin ray. Counts of vertebrae, supraneurals, gill-rakers on the first arch, teeth, and procurrent caudal-fin rays were taken from cleared and stained specimens (c\&s) prepared according to the method of Taylor \& Van Dyke (1985). Tooth counts were also taken in all type specimens. Vertebral counts included the four vertebrae of the Weberian apparatus, and the terminal centrum counted as a single element. Lower and upper jaws of c\&s specimens were prepared for SEM (scanning electronic microscopy) analysis.

Measurements follow Fink \& Weitzman (1974) except the standard length; taken from tip of snout to the last vertebra. Measurements were taken point to point with an electronic caliper on the left side of specimens whenever possible. Measurements are expressed as percents of standard length (SL) except for subunits of the head, which are recorded as percents of head length (HL).

Specimens were examined from the following institutions: ANSP, Academy of Natural Science, Philadelphia; BMNH, Natural History Museum, London; CAS, California Academy of Sciences, San Francisco; MCP, Museu de Ciências e Tecnologia, Pontifícia Universidade Católica do Rio Grande do Sul, Porto Alegre; MHNCI, Museu de História Natural de Capão da Imbuia, Curitiba; MZUEL, Museu de Zoologia da Universidade Estadual de Maringá, Maringá; NMW, Naturhistorisches Museum, Vienna; and ZMB, Museum fur Naturkunde der Humboldt Universität, Berlin.

\section{Astyanax microschemos, new species} Figs. 1-3, Table 1

Holotype. MCP 37569 (55.1 mm SL), córrego Palmital, rio Itapemirim drainage, Iúna, Espírito Santo, Brazil, approx. $20^{\circ} 21^{\prime}$ S $41^{\circ} 31^{\prime} \mathrm{W}, 14$ Jan 2003, R. L. Teixeira \& G. I. Almeida. Paratypes. MCP 34366, 31 (3 c\&s), 35.2-55.1 mm SL, collected with the holotype.

Diagnosis. Astyanax microschemos belongs to the $A$. scabripinnis species complex and differs from species outside this complex by the lower number of branched anal-fin rays (14-18 vs 20-45) and the shallow body depth (26.9-29.7 vs more than $35 \%$ of SL). The combination of the shallow body depth (26.9-29.7\% of SL), and the smaller interorbital width (26.9-30.4\% of HL), versus the deeper body depth (29.7-35.6\% of SL) and greater interorbital width (29.4-38.8\% of HL), distinguish it from remaining species of the complex.

Description. Morphometric data summarized in Table 1. Body compressed and elongate; greatest body depth usually located anterior to dorsal-fin origin. Dorsal profile of head between vertical through posterior nostril and tip of supraoccipital spine straight or slightly convex. Profile of body convex from tip of supraocciptal spine to base of last dorsal-fin ray, and straight from that point to adipose-fin origin. Ventral profile of body slightly convex from vertical through posterior nostril to pectoral-fin insertion, and nearly straight from that point to anal-fin origin. Body profile along anal-fin base posterodorsally slanted. Caudal peduncle elongate and nearly straight to slightly concave along both dorsal and ventral margins.

Snout profile rounded from margin of upper lip to vertical through anterior nostrils. Head small. Mouth terminal, lower jaw slightly longer than upper jaw. Maxilla extending posteri- 




Fig. 2. Astyanax microschemos, MCP 37569, holotype, $55.1 \mathrm{~mm}$ SL; córrego Palmital, rio Itapemirim drainage, Iúna, Espírito Santo, Brazil.

orly to vertical through anterior margin of orbit, slightly curved, and aligned at angle of approximately 45 degrees relative to longitudinal body axis. Anterodorsal border of maxilla concave, posterodorsal border slightly convex, and ventral border convex. Maxilla slightly widened anteroposteriorly.

Premaxilla with two tooth rows; outer row with three pentacuspid teeth with central cusp longer. Five teeth in inner premaxillary row; teeth gradually decreasing in length from first towards fourth teeth with last tooth distinctly smaller: teeth with five to seven cusps with central cusp twice as long and broad as other cusps. Maxilla with two or three (usually two) teeth with tree to five cusps and central cusp longest. Four anterior-most dentary teeth larger, with five or seven cusps, followed by one medium-sized tooth with five cusps, and then four or five teeth with one to three cusps. Central cusp in all teeth two to three times as long and broad as other cusps. All cusp tips slightly curved posteriorly towards inside of mouth (Fig. 3).

Dorsal-fin rays ii, $9(\mathrm{n}=20)$; first unbranched ray approximately one-half length of second ray. Distal margin of dorsalfin nearly straight or slightly convex. Dorsal-fin origin approximately at middle of SL. Adipose-fin located approximately at vertical through insertion of base of last anal-fin ray. Analfin rays iv-v, 15-17 (rarely 14 or 18 , mean $=16.1, \mathrm{n}=20$ ). First unbranched ray normally only apparent in cleared and stained specimens. Distal border of anal fin smoothly concave. Analfin origin situated posterior to vertical through base of last dorsal-fin ray. Pectoral-fin rays i, 11-13 (mean $=11.9, \mathrm{n}=20)$. Tip of pectoral fin falls one or two scales short of vertical through pelvic-fin insertion. Pelvic-fin rays $i, 7(n=20)$. Pelvic-fin origin located slightly anterior to vertical through dorsal-fin origin. Tip of pelvic fin reaching posterior portion of genital open, but falling short of anal-fin origin.

Caudal-fin forked with lobes of similar size and 19 principal rays. Dorsal procurrent rays 9-11. Ventral procurrent rays 9-10 $(\mathrm{n}=3)$.

Scales cycloid, moderately large. Lateral line complete.
Scales in lateral line series $36-38($ mean $=37, n=20)$. Scale rows between dorsal-fin origin and lateral line 5-6 $($ mean $=5.2$, $\mathrm{n}=20$ ); 4-5 scale rows between lateral line and pelvic-fin origin $($ mean $=4.2, \mathrm{n}=20)$. Predorsal scales $10-12($ mean $=$ $10.7, \mathrm{n}=20$ ) arranged in regular series. Scale rows around caudal peduncle $14(\mathrm{n}=20)$. Scale sheath along anal-fin base formed by 4-8 scales in single series covering base of anterior-most rays.

Precaudal vertebrae 17-18; caudal vertebrae 18-19; total vertebrae 35-36. Supraneurals 5-6. Gill-rakers 6/10 $(n=3)$.

Color in alcohol. Dorsal and dorsolateral portions of head and body dark brown. Dark chromatophores scattered on lateral portion of head, but more densely concentrated on snout and anterior border of eye. Dorsal portion of body densely pigmented in larger specimens. Scales on midlateral surface

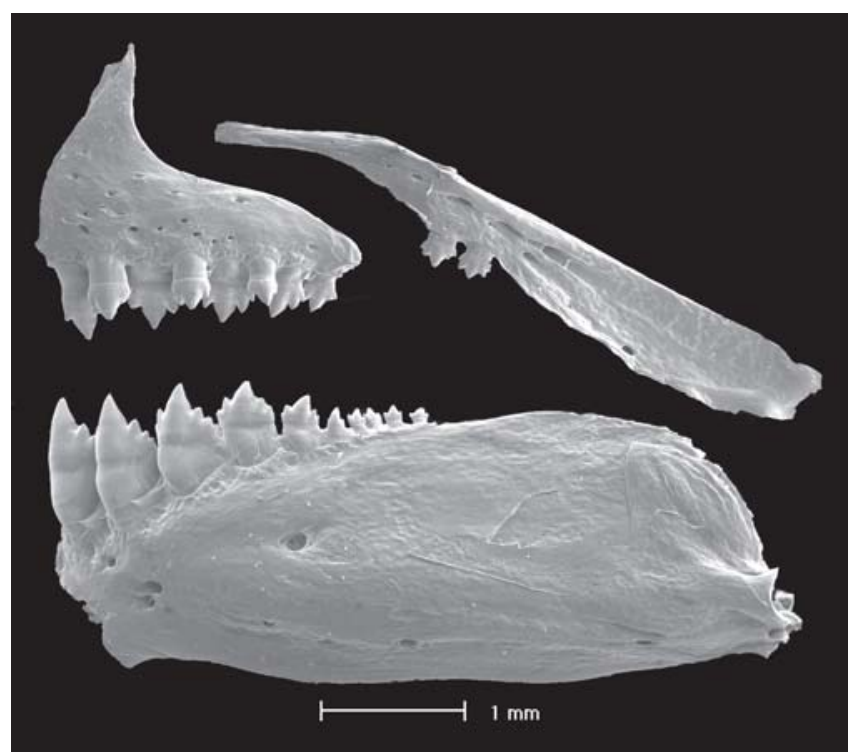

Fig. 3. Astyanax microschemos, MCP 34366, paratype, 46.3 $\mathrm{mm}$ SL. SEM image of left side upper and lower jaws teeth. 
of body bordered with dark brown chromatophores forming reticulate pattern. Body with black, pigmented, midlateral stripe extending from humeral region to base of middle caudal-fin; faint dark pigmentation present of middle caudal-fin rays. Midlateral body stripe expanded dorsally and ventrally proximate to caudal-fin base and forming small caudal spot. Single black, narrow, vertically-elongate humeral spot present with dorsal portion of spot wider. Spot located over second to fourth lateral-line scales and extending over 2 or 3 horizontal series of scales, including lateral line. Fins with scattered dark chromatophores (Fig. 2).

Sexual dimorphism. Secondary sexual characters were not found on examined specimens.

Distribution. Astyanax microschemos is known only from the upper-most headwaters of the rio Itapemirim drainage, a coastal drainage in Espírito Santo State of eastern Brazil (Fig. 1).

Etymology. The species name is from the Greek, mikroschemos, low stature, referring to the shallow body depth of the species.

Ecological notes. At the type-locality the córrego Palmital is about $2 \mathrm{~m}$ wide, with clear water, segments with rapids, riparian vegetation, and a substrate of stones and rocks. Astyanax microschemos was collected with Characidium sp., Neoplecostomus sp. and Trichomycterus sp.

\section{Astyanax pelecus, new species \\ Figs. 1, 4-5, Table 1}

Holotype. MCP 37570 (56.4 mm SL), rio Pardo on road BR116, Cândido Sales, Bahia, Brazil, 1530'49"S 4114'11"W, 21 Jan 1995, J. C. Garavello, S. A. Schaefer, A. S. Santos, J. P. da Silva \& E. H. L. Pereira.

Paratypes. MCP 17919, 8 ( $1 \mathrm{c \& s}), 26.8-60.0 \mathrm{~mm}$ SL, collected with the holotype.

Diagnosis. The following combination of characters distinguishes Astyanax pelecus from its congeners: body depth (26.7-34.8\% of SL), short but pointed snout, that is smaller than the orbital diameter, and reduced number of branched anal-fin rays (16-18). Furthermore, A. pelecus differs from other members of the genus in its distinctive color pattern: it possesses only one humeral spot limited to the region above lateral line series, and has a conspicuous midlateral body stripe extending from the upper margin of the opercle to the caudal-fin base, a putative autapomorphy of this species. Most of the remaining species of Astyanax have humeral spot vertically or horizontally elongate, with an extension of humeral spot ventral to lateral line and have the midlateral body stripe becoming faint or disappearing near, or just anterior to, humeral spot.

Description. Morphometric data summarized in Table 1. Body compressed and elongate; greatest body depth usually situ- ated anterior to dorsal-fin origin. Dorsal profile of head between vertical through posterior nostril and tip of supraoccipital spine straight or slightly convex. Body profile convex from tip of supraoccipital spine to base of last dorsal-fin ray, and straight from that point to adipose-fin origin. Ventral profile of body convex from margin of lower lip to anal-fin origin. Body profile along anal-fin base posterodorsally slanted. Caudal peduncle elongate and nearly straight to slightly concave along both dorsal and ventral margins.

Snout profile rounded from margin of upper lip to vertical through anterior nostrils. Head small. Mouth terminal or slightly sub-terminal with lower jaw slightly shorter than upper jaw. Maxilla extending posteriorly to vertical through anterior margin of orbit, slightly oblique, and at angle of approximately 45 degrees relative to longitudinal body axis. Anterodorsal border of maxilla concave, posterodorsal border slightly convex, and ventral border convex. Maxilla slightly expanded anteroposteriorly.

Premaxilla with two tooth rows; outer row with two to four pentacuspid teeth with central cusp longer. Five or six teeth on inner row, gradually decreasing in length from first to fourth teeth and with last two teeth distinctive smaller. Teeth with five to seven cusps with central cusp twice as long and broad as other cusps. Maxilla with one to four (usually two) teeth with five to seven cusps and central cusp longer. Four or five anterior-most dentary teeth larger than other teeth, with seven cusps and followed by one or two medium sized teeth with five cusps, and six teeth with one to three cusps. Central cusp in all teeth two to three times as long and broad as other cusps. All cusp tips slightly curved posteriorly towards inside of mouth (Fig. 5).

Dorsal-fin rays ii, $9(n=9)$; first unbranched ray approximately one-half length of second ray. Distal margin of dorsal fin straight or slightly convex. Dorsal-fin origin approximately at middle of SL. Adipose-fin located approximately at vertical through insertion of last anal-fin ray. Anal-fin rays iii-v, 16-18 $($ mean $=16.9, \mathrm{n}=9)$. First unbranched ray typically only apparent in cleared and stained specimens. Distal border of anal fin smoothly concave. Anal-fin origin located posterior to vertical through base of last dorsal-fin ray. Pectoral-fin rays i, 11-13 (mean=12.1, $\mathrm{n}=9$ ). Tip of pectoral fin falls three or four scales short of vertical through pelvic-fin insertion. Pelvicfin rays i, $7(n=9)$. Pelvic-fin origin located slightly anterior to vertical through dorsal-fin origin. Tip of pelvic fin reaching posterior portion of genital opening, but falling short of analfin origin.

Caudal-fin forked with lobes of similar size and with 19 principal rays. Dorsal procurrent rays 11. Ventral procurrent rays $10(n=1)$.

Scales cycloid, moderately large. Lateral line complete. Scales in longitudinal series 38-39 $($ mean $=38.3, n=9)$. Five scale rows between dorsal-fin origin and lateral line $(n=9)$; four scale rows between lateral line and pelvic-fin origin ( $\mathrm{n}=$ 9). Eleven to twelve predorsal scales arranged in regular series $($ mean $=11.1)$. Fourteen scale rows around caudal peduncle $(\mathrm{n}=9)$. Scale sheath along anal-fin base formed by 




Fig. 4. Astyanax pelecus, MCP 37570, holotype, 56.4 mm SL; rio Pardo, Cândido Sales, Bahia, Brazil.

four to six scales in single series and covering base of anterior-most rays.

Precaudal vertebrae 16; caudal vertebrae 19; total vertebrae 35. Supraneurals 5. Gill-rakers 6/8 $(n=1)$.

Color in alcohol. Dorsal and dorsolateral portion of head and body dark brown. Dorsal portion of body densely darkly pigmented in larger specimens. Scales on midlateral surface of body bordered with dark brown chromatophores forming reticulate pattern. Snout and anterior border of eye darkly pigmented. Body with black, strongly pigmented, midlateral stripe extending from upper edge of opercle to base of middle caudal-fin rays. Faint dark pigmentation present over middle caudal-fin rays. One small, diffuse dark humeral spot, present. Humeral spot sometimes obscured by midlateral stripe, located over third to fifth lateral line scales, and extending over one or two horizontal series of scales, including lateral line. Fins with scattered dark chromatophores (Fig. 4).

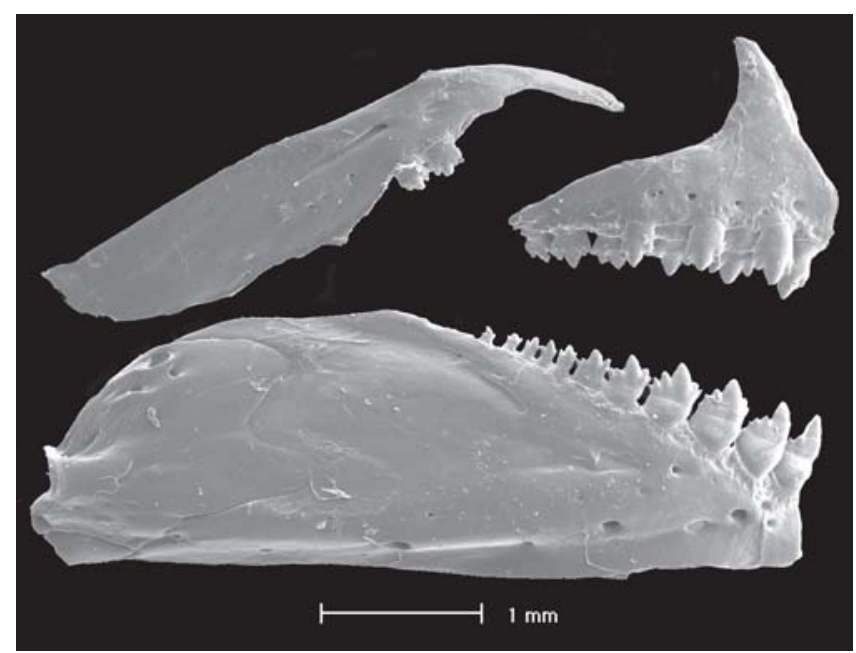

Fig. 5. Astyanax pelecus, MCP 17919, paratype, $51.3 \mathrm{~mm}$ SL. SEM image of right side upper and lower jaws teeth.
Sexual dimorphism. Secondary sexual characters were not found on examined specimens.

Distribution. Astyanax pelecus is known from the upper rio Pardo drainage, at Cândido Sales, a coastal drainage in the state of Bahia, eastern Brazil (Fig. 1).

Etymology. The species name is from the Greek pelekus, meaning axe, in allusion to the form of the dark pigmentation resulting from the junction of the humeral spot with the black midlateral stripe.

Ecological notes. During the dry season, the rio Pardo at the type-locality, is a large river, about 10-20 m wide, with clear water 0.1-1.0 m deep, alternating lentic stretches and rapids, with riparian vegetation that includes grasses. The bottom consists of stones, rocks, sand, and mud. Species collected with Astyanax pelecus were A. cf. bimaculatus, Astyanax sp., Apareiodon itapicuruensis, Characidium sp., Geophagus brasiliensis, Hoplias sp., and Parotocinclus cristatus.

\section{Discussion}

Astyanax microschemos inhabits headwater environments and has the characters, and general body morphology, of the species of the A. scabripinnis species complex that were discussed by Moreira-Filho \& Bertollo (1991) and subsequently by Bertaco \& Malabarba (2001). Astyanax pelecus, on the other hand, with its snout pointed, less massive head, and distinctive color pattern (humeral spot restricted to above the lateral line series; conspicuous dark horizontal stripe), is found in lentic or faint current water, and does not fit the definition of the A. scabripinnis species complex. In face of these distinctive characters of $A$. pelecus we are excluding it of a comparative synopsis of the species, presented below, that likely belong to the $A$. scabripinnis species complex. 
Table 1. Morphometric data of holotypes $(\mathrm{H})$ and paratypes of Astyanax microschemos from the córrego Palmital, rio Itapemirim drainage, Espírito Santo $(\mathrm{n}=20$ including the holotype), and Astyanax pelecus from the rio Pardo drainage, Cândido Sales, Bahia ( $\mathrm{n}=9$ including the holotype).

\begin{tabular}{|c|c|c|c|c|c|c|}
\hline & \multicolumn{3}{|c|}{ A. microschemos } & \multicolumn{3}{|c|}{ A. pelecus } \\
\hline & $\mathrm{H}$ & Range & Mean & $\mathrm{H}$ & Range & Mean \\
\hline Standard length $(\mathrm{mm})$ & 55.1 & $35.2-55.1$ & 44.2 & 56.4 & $26.2-60.0$ & 45.7 \\
\hline \multicolumn{7}{|c|}{ Percents of Standard length } \\
\hline Predorsal distance & 53.5 & $52.6-56.3$ & 54.5 & 52.6 & $51.6-53.7$ & 52.5 \\
\hline Prepelvic distance & 51.0 & $49.9-52.9$ & 51.2 & 51.9 & $50.2-52.7$ & 51.3 \\
\hline Prepectoral distance & 28.7 & $26.7-29.1$ & 28.1 & 23.2 & $23.2-26.7$ & 24.5 \\
\hline Preanal distance & 68.1 & $67.7-71.0$ & 69.4 & 69.5 & $67.3-70.3$ & 68.6 \\
\hline Depth at dorsal-fin origin & 29.0 & $26.9-29.7$ & 28.6 & 33.3 & $26.7-34.8$ & 30.9 \\
\hline Caudal peduncle depth & 12.7 & $11.2-12.7$ & 11.8 & 11.5 & $10.0-12.3$ & 11.3 \\
\hline Caudal peduncle length & 13.6 & $11.2-14.6$ & 13.5 & 11.5 & $11.3-13.2$ & 12.2 \\
\hline Anal-fin base & 21.5 & $19.1-21.5$ & 20.5 & 24.8 & $22.5-24.8$ & 23.6 \\
\hline Dorsal-fin length & 25.0 & $23.3-26.8$ & 24.7 & 24.8 & $24.5-28.3$ & 25.8 \\
\hline Pelvic-fin length & 16.5 & $14.4-16.6$ & 15.8 & 14.8 & $14.8-15.7$ & 15.3 \\
\hline Pectoral-fin length & 22.6 & $20.7-23.1$ & 21.7 & 18.9 & $18.4-21.6$ & 19.5 \\
\hline Head length & 28.9 & $27.2-30.2$ & 28.5 & 23.2 & $23.2-27.1$ & 24.9 \\
\hline \multicolumn{7}{|c|}{ Percents of Head length } \\
\hline Snout length & 25.4 & $19.8-25.6$ & 23.4 & 26.1 & $22.5-26.1$ & 24.4 \\
\hline Upper jaw length & 47.1 & $43.0-47.1$ & 45.3 & 38.9 & $37.5-40.3$ & 39.0 \\
\hline Orbital diameter & 30.3 & $29.7-34.1$ & 32.2 & 31.3 & $31.3-40.6$ & 35.4 \\
\hline Interorbital width & 29.2 & $26.9-30.4$ & 28.9 & 32.7 & $29.4-34.9$ & 31.4 \\
\hline
\end{tabular}

Moreira-Filho \& Bertollo (1991) were the first to characterize A. scabripinnis as a "species complex" as consisting of at least six populations diagnosed on the basis of morphological and kariotypic characters, and occurring in the rio São Francisco basin and upper rio Paraná. Bertaco \& Malabarba (2001) expanded the discussion of the complex with their description of two new species (A.cremnobates and A. brachypterygium) in the complex that, according to those authors, share very low anal-fin ray counts, and are morphologically similar to the subspecies described within A. scabripinnis. Bertaco \& Malabarba (2001) also pointed out that the current diagnosis for $A$. scabripinnis and its subspecies, taken from Eigenmann (1921:273), is apparently common to Astyanax-like forms living in fast current streams, and that distinct but not closely related species sharing this morphological pattern were erroneously considered subspecies of $A$. scabripinnis rather than separate species by Eigenmann $(1921,1927)$.

As defined herein the $A$. scabripinnis species complex is composed of fourteen species in addition to A. microschemos. Astyanax intermedius Eigenmann, 1908 (type-locality: rio Paraíba do Sul, restricted by Melo, 2001), A. laticeps (Cope, 1894) (type-locality: laguna dos Patos system, Rio Grande do Sul, restricted by Malabarba, 1989), A. paranae Eigenmann, 1914 (type-locality: Castro, rio Tibagi drainage, restricted by Garutti \& Britski, 2000), and A. rivularis (Lütken, 1875) (typelocality: rio das Velhas) have been recognized by Eigenmann (1927) as subspecies of $A$. scabripinnis (Jenyns, 1842) (typelocality: Rio de Janeiro). Astyanax jenynsii (Steindachner, 1877), described from the rio Paraíba do Sul and considered a junior synonym of $A$. scabripinnis by Eigenmann (1927), was resurrected by Melo (2001) and is included in the A. scabripinnis species complex (Bertaco \& Malabarba, 2001). Astyanax longirostris (Steindachner, 1907) (rio Cubatão, Águas Mornas), considered a junior synonym of $A$. scabripinnis by Eigenmann (1927), was removed to Deuterodon Eigenmann by Lucena \&
Lucena (2002). The following recently described species are also included in this complex: A. ojiara Azpelicueta \& Garcia, 2000 , from the arroio Benítez, río Uruguay basin, Argentina, $A$. cremnobates Bertaco \& Malabarba, 2001 from the upper tributaries of the rio Jacuí and rio Maquiné drainages, $A$. brachypterygium Bertaco \& Malabarba, 2001 from the upper tributaries of the rio Jacuí and rio Uruguay drainages, $A$. leonidas Azpelicueta \& Casciotta, 2002 and A. troya Azpelicueta $\&$ Casciotta, 2002, both described from the middle portion of the río Paraná, northeastern Argentina, A. ita Almirón et al., 2002 from arroio Tateto, río Iguaçu drainage, Argentina, A. paris Azpelicueta et al., 2002 from the headwaters of arroyo YabotíGuazú, río Uruguay drainage, Argentina, and A. totae Haluch \& Abilhoa, 2005 from upper rio Iguaçu drainage, Paraná, Brazil.

Astyanax microschemos has a humeral spot similar in form to those present in $A$. intermedius and A. jenynsii; however, A. microschemos is distinguished from $A$. intermedius by the smaller interorbital width (32.5-47.8 vs 29.7-34.1\% of HL) and from A. jenynsii by the smaller predorsal length $(21.3-22.6 \mathrm{vs}$ 23.6-26.8\% of SL), and longer anal-fin base length (17.5-19.4 vs $19.1-21.5 \%$ of SL) (data for $A$. jenynsii from Bertaco \& Malabarba, 2001).

The comparison of A. microschemos with A. scabripinnis and $A$.paranae is a difficult task due to the lack of thorough diagnoses for those species. Astyanax scabripinnis was described on the basis of a single specimen collected, according to Jenyns (1842), by C. Darwin during his stay in the city of Rio de Janeiro from April to July, 1832.

Melo (2001) revised the Astyanax species from serra dos Órgãos, and analyzed some specimens from the rio Paraíba do Sul drainage and small drainages flowing to the Baía da Guanabara. Although this is the same region explored by Darwin, Melo did not find any populations that could be clearly recognized as A. scabripinnis. Specimens from the rio dos Macacos were, however, tentatively identified by Melo (2001) 
as A.cf. scabripinnis, with the uncertainty reflective of some morphological discrepancies of that sample versus the holotype of $A$. scabripinnis. We analyzed some specimens from this locality and agreed with Melo (2001). Considering the extensive samples from Rio de Janeiro region examined by Melo (2001) and the strong anthropogenic impacts in the vicinity of that metropolitan area, it is quite possible that $A$. scabripinnis is extinct. Given that possibility we limited our comparisons of A. microschemos to the holotype of $A$. scabripinnis.

Astyanax microschemos differs from A. scabripinnis in the lower number of the anal-fin rays (14-18 vs 21), the lower number of caudal peduncle scales (14 vs 16), the shorter pelvic-fin length (14.4-16.6 vs $22.1 \%$ of SL), the smaller interorbital width (26.9-30.4 vs 40.7\% of HL), and the shorter base of the anal fin (19.1-21.5 vs 30.2\% of SL). Furthermore, the dentary teeth of $A$. microschemos are gradually reduced in size from symphyseal tooth to sixth or seventh tooth, whereas in $A$. scabripinnis the four anterior-most teeth are approximately equally sized and the fifth teeth is very smaller. Astyanax microschemos has one humeral spot similar in form to that of A.cf. scabripinnis, but differs from that species in the shorter anal-fin length (19.1-21.5 vs 21.0-29.4\% of SL), the shallower body depth (26.9-29.7 vs 30.6-35.6\% of SL), and the smaler interorbital width (26.9-30.4 vs 29.9-38.0\% of HL).

Astyanax paranae is usually considered to be a subspecies of A. scabripinnis (Maistro et al., 1998; Garutti \& Britski, 2000). The lack of a clear diagnosis for $A$. paranae has resulted the populations of the scabripinnis complex from rio Paraná, being treated as A. scabripinnis (Mantovani et al., 2000; Maistro et al., 2000). We examined two lots from the upper rio Tibagi drainage: MZUEL 1601 (rio Tibagi at Castro, type-locality of $A$. paranae), and MHNCI 8138 (rio Tibagi, locality of Palmeira). These populations slightly differ from each other in the shape of the humeral spot (upper portion of the humeral spot of specimens from Castro is larger than those from the Palmeira population). However, these differences appear to fall within the expected range of intraspecific variation. Given that both samples came from the type-region of $A$. paranae and that the large examined specimens are morphologically similar to the $A$. paranae holotype we identified these samples as $A$. paranae.

Astyanax microschemos is distinguished from A. paranae by the shallower body depth (26.9-29.7 vs $28.5-33.8 \%$ of SL) and the shorter pre-pelvic length (49.9-52.9 vs 51.0-55.0\% of SL). Astyanax rivularis possesses a body deeper than $A$. microschemos (35.0-46.0 vs 26.9-29.7\% of SL), and is further distinguished from that species by the number of humeral spots $\left(2 v_{s} 1\right)$.

The remaining species of the $A$. scabripinnis complex are: A. brachypterygium, A. cremnobates, $A$. ita, A. leonidas, $A$. ojiara, A. paris, A. totae, and A. troya, all of which inhabit drainages far from the river systems inhabited by $A$. microschemos. These species, except $A$. ita and $A$. totae, differ from $A$. microschemos by the presence of two humeral spots, and by the presence of bony hooks (except $A$. paris) on all fins (in A. ojiara), on the anal- and pelvic-fin rays of males (in $A$. cremnobates, A. brachypterygium, A. ita, and A. totae), and the dorsal-, caudal-, anal- and pelvic-fin rays of males (in $A$. leonidas and $A$. troya) versus presence of the one humeral spot and absence of bony hooks on fin rays in A. microschemos. Furthermore, Astyanax brachypterygium and A.cremnobates have greater predorsal length (55.2-65.3 vs 52.6-56.3\% of SL), and fewer number of cusps on the teeth of the inner tooth row of the premaxilla (3-5 vs 5-7). Astyanax ita, A. ojiara, and $A$. paris differs from $A$. microschemos in the number of branched anal-fin rays (20-24 vs 14-18), and body depth (34.0-40.0 vs 26.9-29.7\% of SL). Astyanax totae differs from A. microschemos by a greater body depth (31.0-35.0 vs $26.9-29.7 \%$ of SL), a smaller orbital diameter (21.6-31.7 vs 29.7-34.1\% of HL), and a higher number of predorsal scales (12-14 vs 10-12, respectively).

Astyanax laticeps, that was recently proposed as distinct from A. scabripinnis by Bertaco \& Malabarba (2001), possesses one oval humeral spot with a narrow anteroventral prolongation which differs from that in A. microschemos.

Astyanax turmalinensis Triques et al. (2003) described from upper rio Jequitinhonha, eastern Brazil, exhibits a deeper body comparatively to the new species, has a small overlap in the range of branched anal-fin rays number with $A$. microschemos (18-21 vs 16-18). Astyanax microschemos differs from A.turmalinensis in the presence of one humeral spot versus two spots, in its head length (27.2-30.2 vs 26.6$28.2 \%$ of SL), and higher number of lateral line scales (36-38 vs 34-36). According to the original description, A. turmalinensis has four teeth in the inner row of premaxilla. We believe this is a mistake given that Astyanax species have five teeth in the inner row of premaxilla.

Astyanax obscurus (Hensel, 1870) was described based in three specimens collected in the rio Cadeia, laguna dos Patos system, Rio Grande do Sul, Brazil. An examination of the syntypes of the species allows the assignment of this species to the A. scabripinnis species complex. It is distinguished from A. microschemos by the presence of two humeral spots and by some morphological differences.

Comparative material. Brazil: Astyanax jenynsii: NMW 57534, 3 syntypes, rio Paraíba. Astyanax laticeps: ANSP 21852, holotype; ANSP 21743, 4 paratypes; Rio Grande do Sul; MCP 26127, 8, arroio Cadeia, Rio Grande do Sul. Astyanax obscurus: ZBM 7478, 3 syntypes, rio Cadea, Rio Grande do Sul. Astyanax cf. obscurus: MCP 17493, 10, rio Taquari drainage, Venâncio Aires, Rio Grande do Sul; MCP 31181, 32, tributary of rio Guaporé, Guaporé, Rio Grande do Sul. Astyanax paranae: CAS 22555, holotype (photograph), Paraná; MZUEL 1601, 9 of 15, rio Lageado, rio Tibagi drainage, Palmeira, Paraná; MHNCI 8138, 9 of 11, tributary of rio Iapó, rio Tibagi drainage, Castro, Paraná. Astyanax rivularis: MCP 36844, 9, rio das Velhas drainage, Santana do Riacho, Minas Gerais. Astyanax scabripinnis: BMNH 1917.7.14.15, holotype, Rio de Janeiro. Astyanax cf. scabripinnis: MCP 20466, 5, arroio Macaquinho; MCP 20467, 6, ribeirão Macacos, Silveiras, São Paulo. Astyanax totae: MCP 37562, 8 paratypes, tributary of rio Tortuoso, an affluent of rio Iguaçu, Balsa Nova, Paraná. Astyanax sp.: MCP 14440, 11, rio Cubatão, rio Paraná drainage, Cajuru, São Paulo; MCP 28089, 55, rio Quebra Anzol drainage, Ibiá, Minas Gerais; MCP 31876, 49, upper rio Doce drainage, Ouro Preto, Minas Gerais; MCP 34629, 12, tributary of rio São João, Fortaleza de Minas, Minas Gerais. 


\section{Acknowledgments}

We are grateful to Marilyn Weitzman (USNM) for information on some type specimens. We owe especial thanks to Vinícius Abilhoa (MHNCI), Oscar Shibatta (MZUEL), James Maclaine (BMNH), and Peter Barstch (ZMB) for the loan of specimens. We thank to Centro de Microscopia e Microanálises - CEMM, PUCRS for the SEM preparations, to Alexandre Charcansky (MCP) for preparing Figures 3 and 5, and to Rogério Teixeira for donation of specimens. This paper benefited from comments and criticisms by Paulo Lucinda (UNT), Luiz Malabarba, and two anonymous reviewers. The senior author is financially supported by the Coordenação de Aperfeiçoamento de Pessoal de Nível Superior (CAPES).

\section{Literature cited}

Almirón, A. E., M. M. Azpelicueta \& J. R. Casciotta. 2002. Astyanax ita sp. n. - a new species from the Río Iguazú basin, in Argentina (Teleostei, Characiformes, Characidae). Zoologische Abhandlungen, 52: 3-10.

Azpelicueta, M. M. \& J. O. Garcia. 2000. A new species of Astyanax (Characiformes, Characidae) from Uruguay river basin in Argentina, with remarks on hook presence in Characidae. Revue Suisse de Zoologie, 107(2): 245-257.

Azpelicueta, M. M., A. E. Almirón \& J. R. Casciotta. 2002. Astyanax paris: a new species from the Río Uruguay basin of Argentina (Characiformes, Characidae). Copeia, 2002(4): 1052-1056.

Azpelicueta, M. M. \& J. R. Casciotta. 2002. Two new species of the genus Astyanax (Characiformes, Characidae) from the Paraná river basin in Argentina. Revue Suisse de Zoologie, 109(2): 243259.

Bertaco, V. A. \& L. R. Malabarba. 2001. Description of new species of Astyanax (Teleostei: Characidae) from headwater streams of Southern Brazil, with comments on the "A. scabripinnis species complex". Ichthyological Exploration of Freshwaters, 12(3): 221-234.

Eigenmann, C. H. 1917. The American Characidae. Part 1. Memoirs of Museum of Comparative Zoology, 43:1-102.

Eigenmann, C. H. 1921. The American Characidae. Part 3. Memoirs of the Museum of Comparative Zoology, 43: 208-310.

Eigenmann, C. H. 1927. The American Characidae. Part 4. Memoirs of the Museum of Comparative Zoology, 43: 311-428.

Eschmeyer, W. 2005. Catalog of Fishes. Electronic publication in "World Wide Web". http://www.calacademy.org/research/ ichthyology/catalog. (4 Aug 2005)

Fink, W. L. \& S. H. Weitzman. 1974. The so-called cheirodontin fishes of Central America with descriptions of two new species (Pisces: Characidae). Smithsonian Contributions to Zoology, 172: 1-46.

Garutti, V. \& H. A. Bristki. 2000. Descrição de uma espécie nova de Astyanax (Teleostei: Characidae) da bacia do alto rio Paraná e considerações sobre as demais espécies do gênero na bacia. Comunicações do Museu de Ciências e Tecnologia da PUCRS, Sér. Zool., Porto Alegre, 13: 65-88.

Jenyns, L. 1842. Fish. Pp. 1-172. In: C. Darwin (ed.). The zoology of the voyage of H. M. S. Beagle, under the command of Captain Fitzroy, R. N., during the years 1832 to 1836 . London. Smith, Elder \& Co.
Lima, F. C. T, L. R. Malabarba, P. A. Buckup, J. F. Pezzi da Silva, R. P. Vari, A. Harold, R. Benine, O. T. Oyakawa, C. S. Pavanelli, N. A. Menezes, C. A. S. Lucena, M. C. S. L. Malabarba, Z. M. S. Lucena, R. E. Reis, F. Langeani, L. Casatti, V. A. Bertaco, C. Moreira \& P. H. F. Lucinda. 2003. Genera incertae sedis in Characidae. Pp. 134-141. In: R. E. Reis, S. O. Kullander \& C. J. Ferraris (Eds.). Check List of the Freshwater Fishes of South and Central America. Edipucrs, Porto Alegre, 729 p.

Lucena, C. A. S. \& Z. M. S. Lucena. 2002. Redefinição do gênero Deuterodon Eigenmann (Ostariophysi: Characiformes: Characidae). Comunicações do Museu de Ciências e Tecnologia da PUCRS, Sér. Zool., Porto Alegre, 15(1): 113-135.

Lütken, C. F. 2001. Peixes do Rio das velhas: Uma contribuição para a Ictiologia do Brasil. Pp. 23-164. In.: C. B. M. Alves \& P. S. Pompeu (Org.). Peixes do Rio das Velhas: passado e presente. Belo Horizonte, SEGRAC.

Maistro, E. L., C. Oliveira \& F. Foresti. 1998. Comparative cytogenetic and morphological analysis of Astyanax scabripinnis paranae (Pisces, Characidae, Tetragonopterinae). Genetics and Molecular Biology, 21(2): 201-206.

Maistro, E. L., C. Oliveira \& F. Foresti. 2000. Sympatric occurrence of two cytotypes of Astyanax scabripinnis (Characiformes, Characidae). Genetics and Molecular Biology, 23(2): 365-369.

Malabarba, L. R. 1989. Histórico sistemático e lista comentada das espécies de peixes de água doce do sistema da laguna dos Patos, Rio Grande do Sul, Brasil. Comunicações do Museu de Ciências e Tecnologia da PUCRS, Sér. Zool., Porto Alegre, 2(8): 107179.

Mantovani, M., L. D. Abel, C. A. Mestriner \& O. Moreira-Filho. 2000. Accentuated polymorphysm of heterochromatin and nucleolar organizer regions in Astyanax scabripinnis (Pisces, Characidae): tools for understanding karyotypic evolution. Genética, 109: 161-168.

Moreira-Filho, O. \& L. A. C. Bertollo. 1991. Astyanax scabripinnis (Pisces, Characidae): a species complex. Revista Brasileira de Genética., 14: 331-357.

Melo, F. A. G. 2001. Revisão taxonômica das espécies do gênero Astyanax Baird \& Girard, 1854 (Teleostei: Characiformes: Characidae) da região da serra dos Órgãos. Arquivos do Museu Nacional, 59: 1-46.

Rosen, D. E. 1972. Origin of the characid fish genus Bramocharax and a description of a second, more primitive, species in Guatemala. American Museum Novitates, (2500): 1-21.

Taylor, W. R. \& G. C. Van Dyke. 1985. Revised procedures for staining and clearing small fishes and other vertebrates for bone and cartilage. Cybium, 9: 107-119.

Triques, M. L., V. Vomo \& E. V. Caiafa. 2003. Astyanax turmalinensis, a new species from the Rio Jequitinhonha basin, Minas Gerais, Brazil (Characiformes: Characidae: Tetragonopterinae). Aqua, Journal of Ichthyology and Aquatic Biology, 7(4): 145-150.

Weitzman, S. H. \& L. R. Malabarba. 1998. Perspectives about the phylogeny and classification of the Characidae (Teleostei: Characiformes). Pp. 161-170. In: L. R. Malabarba, R. E. Reis, R. P. Vari, Z. M. S. Lucena, and C. A. S. Lucena (Eds.). Phylogeny and Classification of Neotropical Fishes. Edipucrs, Porto Alegre. 603p.

Received May 2005 Accepted October 2005 